\title{
Equitable Trusts: An Effective Remedy in Consumer Class Actions
}

\author{
Kerry Barnett
}

The "liberalization" of Rule $23^{1}$ in 1966 brought great hope to those who saw the class action as the answer to a broad range of marketplace abuses. ${ }^{2}$ Twenty years later, many of these expectations have not been met. In particular, for the large consumer class seeking to adjudicate small individual claims, ${ }^{3}$ the class action has proved to be an imperfect and sometimes unworkable device. ${ }^{4}$

Consumer class actions raising small individual claims are often derailed at one of three stages. First, the action may fail through noncertification. ${ }^{5}$ Courts are wary of certifying a class as manageable ${ }^{6}$ when the

I. Fr.D. R. Civ. P. 23.

2. Simon, Class Actions-Useful Tool or Engine of Destruction, 55 F.R.D. 375, 375 (1972); see also State v. Levi Strauss \& Co., 41 Cal. 3d 460, 471, 715 P.2d 564, 570, 224 Cal. Rptr. 605, 611 (1986) ("IT]he consumer class action is an essential tool for the protection of consumers against exploitative business practices.").

3. "Small individual claim" is a relative term. It refers not to any absolute amount, but rather to the value of the claim to the claimant. Thus, it approximates the actual amount of the claim minus the costs of prosecuting it. These costs include the administrative expense incurred by the justice system in adjudicating and processing the claim (since this expense is eventually deducted), and the personal costs to the claimant (in terms of time, energy, aggravation, and out-of-pocket expenses, including legal fees, if any) necessary to prosecute the claim. This expected value of the claim limits the utility to the claimant of prosecuting it.

4. For an excellent example, see In re Hotel Tel. Charges, 500 F.2d 86 (9th Cir. 1974), a class action on behalf of 40 million consumers alleging a conspiracy to inflate hotel charges by imposing a separate fee for telephones. Damages averaged only two dollars per class member. The court refused to certify the class, citing administrative costs and lengthy individual proof of claim proceedings: "In a class of forty million, assuming only ten percent of these unknown class members came forward with claims, and assuming the proof of each claim required only ten minutes, approximately one hundred years would yet be required to adjudicate the claims." Id. at 89 . The hotel owners retained the approximately $\$ 80$ million in alleged overcharges. Id. at 88 .

5. For a discussion of the prerequisites for maintaining a class action under Rule 23, see $1 \mathrm{H}$. Nriwbrikc; Cl.ass $\Lambda$ cilons $\$ 3$ (2d ed. 1985).

6. See FrD. R. Crv. P. 23(b)(3)(D), 23(c)(1). 
sheer size ${ }^{7}$-and often the anonymity-of the plaintiff class effectively prevents proof of damages and compensation on an individual basis. ${ }^{8}$ Daunted, courts sometimes decline to certify the class, ${ }^{\circ}$ and, with individual claims too small to pursue piecemeal, the defrauder ends up keeping the loot.

A second type of failure occurs after judgment. When courts allow the action to proceed beyond certification, the problem is merely delayed, not solved. Following a judgment in favor of plaintiffs, class members must come forward to present individual proofs of claim. However, even when the aggregate damages are enormous, each individual claim may be too small ${ }^{10}$ to be worth the effort for class members to come forward. ${ }^{11}$ Again, the result is frustration of these consumer claims, with unclaimed portions of the recovery fund remaining in the hands of the defendant. ${ }^{12}$

The third problem arises at the settlement stage. The large majority of consumer class actions are settled before trial. ${ }^{13}$ Settlement negotiations are dominated by predictions of how many class members can be expected to present proofs of claim. ${ }^{14}$ Because only a very small number of eligible

7. Very large plaintiff classes are relatively common in consumer class actions. See, e.g., In re Memorex Sec. Cases, 61 F.R.D. 88, 93 (N.D. Cal. 1973) (SEC violations alleged by 60,000 class members); Zachary v. Chase Manhattan Bank, 52 F.R.D. 532, 534 (S.D.N.Y. 1971) (consumer credit case involving more than one million class members); Eisen v. Carlisle \& Jacquelin, 52 F.R.D. 253, 257 (S.D.N.Y. 1971) (Sherman Act violation alleged by six million plaintiffs), rev'd, 479 F.2d 1005, 1008 (2d Cir. 1973), vacated and remanded, 417 U.S. 156, 166 (1974); Bruno v. Superior Court, 127 Cal. App. 3d 120, 123, 179 Cal. Rptr. 342, 343 (1981) (milk price fixing alleged by 1 to 1.5 million consumers).

8. Often, extraordinary measures-such as advertising in the mass media, employing professional locator services, hiring staff, and appointing special masters-can be devised, but only at a cost disproportionate to the size of each individual claim, vastly diminishing the efficacy of any recovery.

9. See, e.g., Ralston v. Volkswagenwerk, 61 F.R.D. 427, 428 (W.D. Mo. 1973) (18,000 automobile purchasers charged price fixing on Volkswagens); Philadelphia v. American Oil Co., 53 F.R.D. 45, $72-74$ (D.N.J. 1971) (six million consumers alleged gasoline price fixing); Cicelski v. Sears, Roebuck \& Co., 132 Mich. App. 298, 304, 348 N.W.2d 685, 689 (1984) (approximately one million consumers claimed miscalculation of department store finance charges).

10. See, e.g., In re Hotel Tel. Charges, 500 F.2d 86, 88 (9th Cir. 1974) (forty million plaintiffs with average claim of two dollars each); Ohio Pub. Interest Campaign v. Fisher Foods, 546 F. Supp. $1,10-11$ (N.D. Ohio 1982) (1.1 million class members with estimated maximum damages of $\$ 3.83$ to $\$ 6.77$ each); Cicelski v. Sears, Roebuck \& Co., 132 Mich. App. at 303, 348 N.W.2d at 688-89 (maximum average individual claim of $\$ 4.50$ out of aggregate class-wide damages of $\$ 1$ million).

11. Even when consumers are willing to come forward, in many cases they will be unable to prove their claims, having long since discarded receipts, records, or even the purchased item itself. Of course, when the consumer is certain that he or she made the purchase, courts may accept a sworn affidavit in lieu of documentation. However, without documentation or the item itself, consumers may not remember whether the purchase was made, when it was made, or how many items were purchased.

12. See, e.g., Illinois Bell Tel. Co. v. Slattery, 102 F.2d 58, 61-62 (7th Cir. 1939) (defendant entitled to keep $\$ 1.69$ million of damage fund that could not be refunded to class members).

13. See 2 H. Newrirg, supra note $5, \S 11.14$.

14. Telephone interview with Beverly C. Moore, Jr., Editor of Class Action Reports (Nov. 7, 1985). The number of class members expected to present proofs of claim, multiplied by the average claim, determines the maximum possible loss a defendant can sustain at judgment. Therefore, this number also determines the maximum amount a defendant will pay in settlement, since no defendant 
class members ever come forward, plaintiffs are forced to settle for a fraction of the damages they claim-five cents on the dollar is typical. ${ }^{15}$ Thus, even when a class is certified, the requirement that individuals prove damages in mass consumer class actions may have the practical effect of foreclosing recovery on a large portion of the class's damages. As a result, the offending party profits.

To correct these inequities, courts should weigh the manageability of small claim consumer class actions against the goals of disgorgement and deterrence, ${ }^{16}$ instead of against the traditional goal of compensation. Judges should then fashion remedies to satisfy these goals; ${ }^{17}$ while these remedies may not provide full direct compensation to plaintiffs, they can force guilty defendants to disgorge ill-gotten gains, and deter them from similar future conduct. ${ }^{18}$ To do this, courts should: (1) decline to require individual proofs of claim in cases where the aggregate class-wide damages can be calculated; and (2) utilize the doctrine of cy pres ${ }^{19}$ to distribute the recovery fund in a class-wide fashion. A cy pres mechanism that is particularly well-suited to small claim consumer class actions is the equitable trust.

This Note argues for legislative and judicial action to expand the use of equitable trusts. Section I presents three goals for small claim consumer class actions that justify the use of $c y$ pres recoveries. Section II suggests criteria for evaluating different $c y$ pres distributions and finds the common cy pres options inadequate. Section III discusses the structure and application of equitable trusts, as well as the potential for expanding their use. Section IV offers guidelines for legislative action to direct the courts' exercise of the equitable trust remedy.

will setule a case for more than it expects to lose at trial. (This does not take into account lawyers' fees and court costs, which would, of course, increase defendants' potential losses at trial.)

15. Id.

16. See infra Section I.B.

17. See Sindell v. Abbott Laboratories, 26 Cal. 3d 588, 610, 607 P.2d 924, 936, 163 Cal. Rptr. 132,144 (courts must fashion consumer class action remedies to meet changing needs of society), cert. denied, 449 U.S. 912 (1980).

18. State v. Levi Strauss \& Co., 41 Cal. 3d 460, 472, 715 P.2d 564, 570-71, 224 Cal. Rptr. 605, 611-12 (1986) ("Fluid recovery may be essential to ensure that the policies of disgorgement or deterrence are realized. Without fluid recovery, defendants may be permitted to retain ill-gotten gains simply because their conduct harmed large numbers of people in small amounts instead of small numbers of people in large amounts.") (citation omitted).

19. "As near as (possible)." Bl.Ack's Law Dicrionary 349 (5th ed. 1979). Cy pres, borrowed from the law of trusts, suggests that when direct compensation to the victims of defendant's conduct is not feasible, the recovery should be distributed in a "next best" fashion-through indirect compensation (e.g., coupons, merchandise, price reductions, services, advocacy, etc.) -or to a class that is not identical to the aggrieved class. Colson v. Hilton Hotels, 59 F.R.D. 324, 326 (N.D. Ill. 1972) (example of "fluid class" concept: compensating current hotel users if past users cannot feasibly be compensated). 


\section{Goals For Small Claim Consumer Class Actions}

Consider the goals of a system that seeks to adjudicate small claim consumer class actions. This Note focuses on three goals of fundamental importance to the issue of damage fund distribution: direct compensation, disgorgement and deterrence, and equity for absentee class members. These goals provide the basic rationale for $c y$ pres recoveries.

\section{A. Direct Compensation}

Class members with valid claims should receive direct compensation; that is, they are entitled to be made whole. The court assigns a monetary value to the injury and the victim receives a direct payment for that amount. In the case of consumer fraud, the defendant's illegal profits originally belonged to the victims and therefore are returned directly to them.

However, in class actions with very large plaintiff classes and small individual claims, direct compensation is often not feasible. ${ }^{20}$ Individual proofs of claim may be too time-consuming and difficult to administer. ${ }^{21}$ Or, the costs of locating class members, communicating with them, evaluating their proofs of claim, and distributing payments may be so large relative to the size of the individual claim as to result in a claim of little practical compensatory value. ${ }^{22}$ In other cases, members of the plaintiff class may be difficult to locate regardless of the resources brought to bear because the victims may be unaware that they are members of the class. ${ }^{23}$ For example, if a suit alleged price fixing of a common consumable household good, many class members might not recall the brand they purchased, when and where they purchased it, or even that they purchased it at all. In all likelihood, they have long since discarded any proof of purchase. Similarly, if a suit involved overcharges of pay telephone users, most class members would be unable to calculate accurately the number of pay telephone calls they made during the relevant period of time. Although it may be impossible to compensate class members directly in such a case, it may well be possible to prove defendants' liability to the class.

20. See, e.g., Blue Chip Stamps v. Superior Court, 18 Cal. 3d 381, 385-86, 556 P.2d 755, 758, 134 Cal. Rptr. 393, 396 (1976); see also supra notes 4, 9. Direct compensation may not be feasible in other types of class actions as well. See infra note 95.

21. See, e.g., In re Hotel Tel. Charges, 500 F.2d 86, 89 (9th Gir, 1974), discussed supra note 4.

22. Cicelski v. Sears, Roebuck \& Co., 132 Mich. App. 298, 348 N.W.2d 685 (1984), provides an extreme example of administrative costs that eclipse the claim. Plaintiffs alleged excessive finance charges on retail installment sales contracts, amounting to $\$ 1$ million. The court found that it would cost more than $\$ 82$ million to determine the class members' individual claims, plus an additional "enormous expense" for mailings, printing, and processing. Id. at 303, 348 N.W.2d at 688-89. Due to these costs, the court declined to certify the class.

23. See, e.g., Illinois Bell Tel. Co. v. Slattery, 102 F.2d 58 (7th Cir. 1939). Despite efforts that lasted three years, employed as many as 2,000 people at one time, and cost $\$ 2.7$ million, defendrut was still unable to locate class members entitled to refunds totalling $\$ 1.69$ million. Id. at $61-62$. 
The important issue is how to determine the point at which direct compensation is no longer feasible. ${ }^{24}$ The court must decide what level of administrative costs it will allow in a particular case. These costs should be determined relative to the amount of individual recoveries. Not surprisingly, courts are loathe to commit valuable judicial resources to cases in which the ratio of administrative costs to the total recovery is so large that each victim is unlikely to receive meaningful compensation and only the lawyers prosper. ${ }^{25}$

\section{B. Disgorgement and Deterrence}

Even when it is not feasible to compensate class members directly, the important public policy goals of disgorgement and deterrence should be satisfied. It is a basic principle of equity that wrongdoers should not profit from their wrongdoing. ${ }^{26}$ Society benefits, even if the victims do not, when courts devise remedies that force defendants to relinquish ill-gotten gains. Wrongdoers will be less likely to engage in future illegal acts if the incentive of unjust enrichment is eliminated. If future transgressions-and litigation-can be reduced, then ensuring deterrence is a valuable long-run application of judicial resources, even in cases where class members cannot feasibly be compensated directly.

\section{Equity for Absentee Class Members}

Consumer classes in small claim actions are often characterized by a large percentage of absentees. ${ }^{27}$ Modern market strategies target many millions of consumers at once; a single marketplace abuse may therefore injure a very large number of people. ${ }^{28}$ Current law, however, provides no relief to a victim who is not identified to the court, or who cannot or will not come forward to prove a claim. When the court can infer the existence of these injured individuals from the evidence and can calculate the aggregate amount of claims, the class action device ought to permit satisfaction of the claims.

A free-market, competitive economy encourages marketplace fraud as a

24. See infra Section IV.A. \& B.

25. See In re Hotel Tel. Charges, 500 F.2d 86, 91-92 (9th Cir. 1974). Nonetheless, courts should consider the consequences of declining to permit an action to go forward because of high administrative costs. Refusal to bear these costs is tantamount to denial of the claim, however meritorious it might be, when individual claims are so small that no alternative for prosecuting the claim exists outside the class action device.

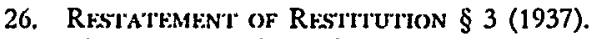

27. Absentees are individuals who have been injured by a defendant's conduct and fall within the class definition contained in the complaint, but who remain anonymous and uninvolved in the litigation because it is unfeasible or impossible to identify them, or because sufficient efforts to identify them have not been undertaken.

28. See supra note 7 . 
viable profit source when the legal system limits the remedies available to the victims. In an economy in which anonymous transactions are very common, a class action recovery mechanism that compensates only identifiable victims and ignores absentee victims encourages abuse. The likelihood that the defendant will profit from its wrongdoing-even if it gets caught ${ }^{29}$-constitutes a significant hidden cost to society of disregarding claims of absentee class members.

Further, equity demands that the recovery of one victim should not unreasonably be given priority over that of another. Compensation of identifiable claimants should not be so costly aș effectively to foreclose the prospects of even alternative recovery by absentee claimants. Absenteeism does not necessarily suggest a less serious injury, 'or even an ambivalent attitude towards pressing a claim. Often, absenteeism is simply a result of not receiving one's mail, not reading newspapers, ${ }^{30}$ lack of understanding of one's legal rights, ${ }^{31}$ faulty memory, failure to retain sales receipts and other supporting documents, ${ }^{32}$ or the economics of very small individual claims that justify only minimal individual effort. ${ }^{33}$ From the perspectives of both the victims and society as a whole, the losses of absentees are no less serious than the losses of named and readily identifiable plaintiffs. All injuries deserve the same equitable resolution.

\section{Choosing Among Cy Pres Options}

The above three goals provide the foundation for cy pres recoveries. Complete disgorgement-which includes the illegal gains from absentees-requires aggregation of class-wide damages. Once the court forces the defendant to disgorge this amount, the court must determine what to do with the money when direct compensation is not feasible. Unless the recovery fund is literally burned, its benefit must accrue to someone. Equity suggests that, as nearly as possible, the benefit should accrue to the injured, including the absentees. ${ }^{34}$ When it is impossible to do this directly, it should be done indirectly, with the goal of providing at least

29. See, e.g., In re Hotel Tel. Charges, 500 F.2d 86 (9th Gir. 1974), discussed supra note 4.

30. See $2 \mathrm{H}$. NewBEk, supra note $5, \S 8.24$ (mail and publication in press are common methods of class notification).

31. See Rhode, Class Conflicts in Class Actions, 34 STAN. L. REv. 1183, 1234-36 (1982) (potential class members unable to understand meaning of notices).

32. See State v. Levi Strauss \& Co., 41 Cal. 3d 460, 471-72, 715 P.2d 564, 570, 224 Cal. Rptr. 605,611 (1986) ("[C]onsumers are not likely to retain records of small purchases for long periods of time.").

33. Id. ("Each individual's recovery may be too small to make traditional methods of proof worthwhile.").

34. See Rrsiathmini (Skcond) OF Tor's \$ 910 (1977). 
some significant benefit to the class. This is the concept of cy pres, as applied to class actions. ${ }^{36}$

Once the court, in its discretion, ${ }^{36}$ determines that a "next best" recovery is the only practical way to achieve the above goals, the court must determine what the next best option is. It should begin by identifying the criteria by which various options should be evaluated. ${ }^{37}$ Generally, these criteria track the previous discussion. First, any "next best" recovery mechanism should seek to compensate the class as directly and accurately as possible. ${ }^{38}$ Over- and under-compensation should be avoided. The possibility of leaving a portion of the class out of the recovery, or allowing non-members to share in the recovery, should be minimized. Second, administrative and adjudicative costs should be minimized. ${ }^{39}$ Holding down these costs conserves judicial resources and allows greater benefit to accrue to the injured class. Third, defendants should completely disgorge any illegal gain. Complete disgorgement deters future violations. Fourth, private attorney general actions-lawsuits brought by private citizens to enforce statutes that the government has enacted as sound policy, but is unable or unwilling to enforce vigorously-should be encouraged..$^{40}$ Adequate recovery funds and fee awards provide motivation for claimants and attorneys, respectively. ${ }^{41}$ In addition, this fourth criterion favors applications of the recovery fund that empower class members to press claims and assert rights on their own behalf in a variety of matters consistent with statutory policy. ${ }^{12}$ This, in turn, promotes the goals of compensation, disgorgement and deterrence. Finally, as noted above, ${ }^{43}$ intra-class equities should be

35. See generally Note, Damage Distribution in Class Actions: The Cy Pres Remedy, 39 U. CHI. L. Rk.V. 448, 452-53 (1972) (describing cy pres doctrine as applied to class actions).

36. For a legislative proposal to guide the courts' exercise of this discretion, see infra Section IV.

37. See, e.g., State v. Levi Strauss \& Co., 41 Cal. 3d 460, 473, 715 P.2d 564, 571, 224 Cal. Rptr. $605,612(1986)$.

38. See, e.g., In $r e$ "Agent Orange" Prod. Liab. Litig., 597 F. Supp. 740, 859 (E.D.N.Y. 1984) (goal of distribution is to "assure acceptable targeting of limited settlement funds").

39. Id. ("Transaction costs . . . must be kept to a minimum.").

40. See generally Note, Important Rights and the Private Attorney General Doctrine, 73 Cal.r. L. Rkv. 1929, 1929-30 (1985) (describing private attorney general paradigm).

41. See Lee v. Southern Home Sites Corp., 444 F.2d 143, 147-48 (5th Cir. 1971) (attorney fees awarded to encourage private attorney general enforcement of housing anti-discrimination statute); Tenants and Owners in Opposition to Redevelopment v. United States Dep't of Hous. and Urban Dev., 406 F.Supp. 1060, 1064 (N.D. Cal. 1974) (award of attorney fees based on private attorney general doctrine). See generally Nussbaum, Attorney's Fees in Public Interest Litigation, 48 N.Y.U. L. Rrv. 301 (1973) (discussing importance of attorney fee awards to encourage public interest litigation).

42. For example, in Lee v. Southern Home Sites Corp., 444 F.2d at 147-48, the court held that "[t]he policy against discrimination in the sale or rental of property ... depends entirely on private enforcement," and therefore an award of attorney fees for plaintiffs was warranted "[t]o ensure that individual litigants are willing to act as 'private attorneys general' to effectuate the public purposes of the statute ...." In the same way, a class action recovery fund could be applied to provide private attorney general enforcement of statutory policy.

43. See supra Section I.C. 
preserved; that is, the rights of absentee class members should not be subordinated to those of identifiable plaintiffs.

Courts have attempted various $c y$ pres remedies in mass consumer class actions, but measured against these criteria, they fall short.

\section{A. Price Mechanism}

One option is to recoup plaintiffs' losses by forcing the defendant to reduce the price of its consumer goods for a specified period. A "price mechanism" 44 of this sort both compensates consumer class members and also serves the goals of disgorgement and deterrence. However, circumstances are rare in which courts can successfully apply this mechanism. In an ordinary market, ${ }^{45}$ for instance, the court-ordered price reduction may drive up the number of units sold by the defendant, thereby diluting the intended disgorgement and deterrence effects. ${ }^{46}$ The price reduction would force competitors to either lower prices or lose market shares. ${ }^{47}$ The price mechanism may be useful, however, in a monopolistic market where there are no competitors to be affected by the market distortions. Yet even in

44. See Colson v. Hilton Hotels Corp., 59 F.R.D. 324 (N.D. Ill. 1972) (settlement agreement in antitrust action in which $50 \notin$ hotel room rate reduction credited to future guests); Eisen v. Carlisle \& Jacquelin, 52 F.R.D. 253 (S.D.N.Y. 1971) (odd-lot fee differential price reduction proposed), rev'd, 479 F.2d 1005 (2d Cir. 1973), vacated and remanded, 417 U.S. 156 (1974); Daar v. Yellow Cab Co., 67 Cal. 2d 695, 433 P.2d 732, 63 Cal. Rptr. 724 (1967) (cab fares reduced to compensate for previous overcharges) (settlement described in 2 H. NiwBERG, supra note 5, $\$ 11.20$, at 416 n.60); Feldman v. Quick Quality Restaurants, N.Y.L.J., July 22, 1983, at 12, col. 4 (N.Y. Sup. Ct., N.Y. County, July 15, 1983) (class certification) (coupons for free food distributed by fast food restaurant in consumer fraud action) (settlement described in 3 H. NkwBERG, supra note 5, $\$ 13.46$, at 90) (consent order on file with author).

45. This assumes a market in which there is some competition, but even after the court-ordered price reduction, the price is above marginal cost.

46. See State v. Levi Strauss \& Co., 41 Cal. 3d 460, 473-74, 715 P.2d 564, 572, 224 Cal. Rptr. 605,613 (1980) (decrease in price will increase defendant's market share to detriment of competitors). See generally Note, An Economic Analysis of Fluid Class Recovery Mechanisms, 34 STAN. L. Rev. $173,186-200$ (1981) (indicating deficiencies of price mechanism form of fluid class recovery). Using other types of price mechanisms to adjust for this increase in sales will result in related problems. For instance, a market distribution mechanism that involves special rebates, paid for by the defendant and given to customers of defendant's competitors, would succeed in depriving the defendant of any market benefits from a lowered price. The defendant would then either lower its price or lose market share. All purchasers, whether victims of the defendant's fraud or not, would benefit from the distribution. Further, price mechanisms could alter consumers' buying habits and loyalties and thus have a longterm skewing effect on the market. The result could be a detrimental impact on the defendant in excess of its liability under the lawsuit. Such a program would likely have significant administrative costs as well.

Another problem with the price mechanism is that consumers will "compete" to purchase the goods at the lower price. They will be willing to stand in lines and travel longer distances to take advantage of the reduced price. These inconvenience costs will mount until they equal the price reduction. Thus, consumers will receive no real benefit. Id. at 189-90.

47. This adverse effect on competitors would also occur in a perfectly competitive market (i.e., price equals marginal cost). The price mechanism would force the price below marginal cost. ' $\Gamma 0$ minimize loss, the defendant would decrease production. If the court mandated output sufficient to meet demand, innocent competitors would be forced to lower prices or suffer reduced sales. 
this situation there is a danger that, as a result of the price reduction, defendant's goods or services will diminish in quality, denying the consumer any real benefit. This is avoided only if the court or an administrative agency is able to control for reductions in quality.

Another difficulty with the price mechanism is the imperfect "fit" between the injured class and the class benefitting from the recovery. Next year's buyers of a given commodity may not be identical to last year's buyers. ${ }^{48}$ Finally, monitoring costs of the price mechanism will vary with the circumstances, but will likely be considerable.

\section{B. Escheat to the Government}

Distribution of the recovery fund to the government is another option. ${ }^{48}$ Escheat is attractive because it achieves full disgorgement with very low administrative costs. The problem is that government use of the funds, as part of general welfare allocations, results in a benefit to a class far larger than the class of people actually injured by defendant's conduct. ${ }^{50}$ Any direct benefit to injured class members may be trivial.

Even if the court were to require use of the escheated funds for a particular purpose selected to coincide with the interests of the plaintiff class, ${ }^{51}$ problems remain. First, if the project is also supported by budget allocations from the legislature, there is nothing to prevent the legislature from scaling back its own allocations in an amount equal to the escheat. Second, it is conceivable that the court might order a use of the funds that contradicts the legislative will. ${ }^{62}$ This would raise serious separation of powers concerns.

48. This is particularly true when the commodity is a relatively expensive durable good such as an automobile or an appliance, since consumers purchase these items only rarely. One possible solution is to attach the price mechanism to recurring costs related to these items, such as service, replacement parts, or accessories. The problem of potential long-term changes in consumers' buying habits and loyalties remains, however.

49. See, e.g., In re Folding Carton Antitrust Litig., 744 F.2d 1252 (7th Cir. 1984) (unclaimed portion of price fixing suit recovery fund escheats to federal government); Hansen v. United States, 340 F.2d 142 (8th Cir. 1965) (unclaimed balance of recovery fund in rent control suit remains in U.S. Treasury account); Vecchione v. Wohlgemuth, No. 73-162 (E.D. Pa. Apr. 22, 1982) (unclaimed balance of common fund for class of mental patients escheats to state).

50. State v. Levi Strauss \& Co., 41 Cal. 3d at 475, 715 P.2d at 572, 224 Cal. Rptr. at 613.

51. See, e.g., West Virginia v. Chas. Pfizer \& Co., 314 F. Supp. 710 (S.D.N.Y. 1970), affd, 440 F.2d 1079 (2d Cir. 1971) (antitrust settlement on behalf of pharmaceutical consumers in which unclaimed balance of recovery fund given to states for public health uses).

52. This potential for conflict is demonstrated in Simer v. Rios, 661 F.2d 655 (7th Gir. 1981), cert. denied, 456 U.S. 917 (1982), a class action brought on behalf of consumers improperly denied emergency energy relief funds. The court approved a settlement that required a cy pres application of a damage fund to be administered by the same government agency that was the defendant in the action. The money was to fund a variety of energy relief programs-programs that Congress had recently decided to cease funding. The settlement approval was overturned due to this apparent conflict with legislative policy. Simer v. Olivarez, No. 79 C 3960 , slip op. at 5 (N.D. Ill. Oct. 29, 1980). 


\section{Claimant Fund Sharing}

A third option is claimant fund sharing, that is, dividing the aggregate damages pro rata among identifiable class members. ${ }^{53}$ This approach, too, succeeds in deterring and disgorging, but its compensatory approach is equitable only when one can expect all but an insignificant number of class members to come forward to share in the recovery. Absentees receive no recovery whatsoever. Further, to the extent that absentees fail to recover, class members who do step forward are over-compensated. This method is particularly ill-suited to class actions involving small individual claims, since a large number of absentees is expected.

\section{The Equitable Trust}

This Note argues that the best option for most small claim consumer class actions is a single, class-wide distribution. Courts can avoid piecemeal recoveries and individual proofs of claim by allowing the fund to remain in a concentrated lump. Courts also avoid the administrative costs inherent in individual disbursements. Disgorgement is complete. Intraclass inequities are avoided since no disproportionate share of the recovery is spent administering any individual recoveries, and all class members-including absentees-share equally in the recovery. A class-wide recovery has intuitive appeal: a group of individuals is injured by the same illegal act, they assert their legal rights as a class, they prove defendant's liability to the class; it is hardly inconsistent that they receive their recovery as a class.

This class-wide distribution should take the form of an equitable trust designed to benefit the injured class. For example, in Vasquez v. Avco Financial Services, ${ }^{54}$ a class action alleging excessive interest rates on retail installment sales loans, the bulk of the recovery fund was placed in trust with a consumer organization to fund advocacy, research, and education regarding consumer credit transactions-all on behalf of consumers. ${ }^{\mathrm{ss}}$ Thus, recoveries from class actions can be applied toward such beneficial activities as administrative intervention before regulatory agencies, lobbying on key consumer issues before legislative bodies, funding for enforcement actions of state and federal consumer protection statutes, research and educational activities around health and safety issues, and consumer product testing.

53. See, e.g., Beecher v. Able, 575 F.2d 1010 (2d Cir. 1978) (federal securities violations); Stewart v. General Motors Corp., 542 F.2d 445, 452-54 (7th Cir. 1976) (race discrimination in hiring and promotion); Phemister v. Harcourt Brace Jovanovich, Inc., No. 77 C 39 (N.D. Ill. Sept. 14, 1984) (Sherman $\Lambda$ ct violations regarding bar review business).

54. No. NCG 11933B (Super. Ct., Los Angeles, Sept. 23, 1975),

55. Id. (Order Re Cy Pres Remedy, Atorney's Fees and Costs, filed April 24, 1984). 
Strong policy considerations particularly favor creation of equitable trusts in consumer class actions in which individual disbursements, were they attempted, would be so small as to be of trivial ${ }^{56}$ value to class members. ${ }^{87}$ When aggregated into a large fund, trivial amounts of money are capable of conferring benefits upon class members that are not at all trivial. ${ }^{58}$ For example, what would be spare change in the pockets of utility consumers, if aggregated into a central, class-wide fund, could provide ad-

56. "Trivial" here means an amount so small that the claimant is indifferent to collection. This refers only to indifference regarding the amount of the claim; claimants might not be indifferent to recovery out of a concern with punishment, disgorgement, or deterrence, or simply a desire to vindicate their claims. Of course, this notion of triviality is relative to the claimant's wealth.

57. There are two situations in which individual recoveries are of trivial value. The first involves cases in which the injury is significant, but the cost of administering direct compensation would burn up all but an extremely small portion of the recovery. For example, in State v. Levi Strauss \& Co., 41 Cal. 3d 460, 464, 715 P.2d 564, 565, 224 Cal. Rptr. 605, 606 (1986), the damages per pair of jeans were only 35 to 40 cents after administrative costs were deducted. In Cicelski v. Sears, Roebuck \& Co., 132 Mich. $\Lambda$ pp. 298, 348 N.W.2d 685 (1984), a case involving excessive finance charges on credit sales agreements, the court refused to certify the class, citing likely per claim administrative costs of up to seventeen-and-one-half times the average claim. Id. at 303,348 N.W.2d at 688-89. A single, class-wide recovery is appropriate in these circumstances because class members who lose something of value at the hands of the defendant deserve something of value in return. An indirect recovery of significant value is preferable to a direct recovery of insignificant value.

Second, the magnitude of an injury may be so slight that only trivial relief is justified. For example, price fixing, misrepresentation, defect, or fraud on inexpensive consumer goods might yield an extremely large plaintiff class with very small individual injuries, ranging from a few cents to several dollars. See supra note 10. Here, an equitable trust is also warranted. Basic principles of economic efficiency favor using the recovery fund to confer significant benefits on the plaintiff class. Scarce judicial resources encourage maximization of participants' return from each judicial dollar expended. It is this nontrivial benefit that provides incentives to challenge marketplace abuses in the first place. In many cases, these benefits, even if nontrivial, are still small enough to warrant very little effort by individual consumers to prosecute these claims. Most often, the attorney, spurred on by potential fees that are nontrivial indeed, has the incentive to prosecute small claim mass consumer class actions. Still, it is important to ensure that significant benefits accrue to class members for at least two reasons: First, without it, there would be nothing other than moral indignation to justify even minimal cooperation by consumers with the "crusading" attorney; and second, it adds at least a veneer of respectability to what would otherwise be an unseemly legal spectacle-a massive lawsuit on behalf of a huge class that will receive no meaningful benefits.

The concern is not only with trivial direct compensation, but also with any type of trivial individual disbursement, even if cy pres in nature. The point is that a particular type of cy pres recovery, one involving a single, lump-sum class-wide disbursement, is preferable to individual disbursements. For examples of class action recoveries of dubious value, see Ohio Pub. Interest Campaign v. Fisher Foods, Inc., 546 F. Supp. 1, 5 (N.D. Ohio 1982) (supermarket price fixing case in which class members received one dollar food coupons usable at rate of two coupons in each of ten consecutive sixmonth periods; unclaimed coupons were donated to the poor); Colson v. Hilton Hotels Corp., 59 F.R.D. 324 (N.D. Ill. 1972) (fee opinion) (hotel room rates were temporarily reduced by $50 \$$ per night); Grossman v. Playboy Clubs Int'l, Civil No. 882,939 (Cal. Super. Ct. 1969) (class members received token worth $\$ 8$ in Playboy Clubs), cited in $2 \mathrm{H}$. NrwBrRg, supra note 5, $\$ \$ 11.45,12.05$.

58. See, e.g., In re "Agent Orange" Prod. Liab. Litig., 611 F. Supp. 1396 (E.D.N.Y. 1985). In justifying its decision to approve a distribution plan that allocated one-quarter of a $\$ 180$ million settlement fund to create a class assistance foundation, the court said:

Distribution of thousands of small individual payments would trivialize the beneficial impact

of the settlement fund on the needs of the class. . . Because the foundation will direct the spending of a large pool of money to fund services, it will have a greater impact on the problems of the class than if thousands of small, individual payments were made.

Id. at 1431-32. 
vocacy before state public utility commissions to secure lower utility rates, more favorable pricing structures, or better service-all tangible, substantial benefits for these consumers. Alternatively, the recovery fund might be used for research, development and testing of new energy-conservation techniques capable of saving each consumer hundreds of dollars. ${ }^{59}$

Establishing an ongoing institution ${ }^{60}$ designed to provide benefits over time is preferable to providing class members with a one-time disbursement of relatively worthless sums. This is particularly true when one considers that the use of the fund can be tailored to mirror the same policy objectives as the statute or common law doctrine under which the action was brought. ${ }^{61}$ The ongoing social benefits of deterrence alone justify this application of the recovery fund.

\section{A. Structuring an Equitable Trust}

Once defendant's liability has been established and aggregate damages determined, the court should solicit-from a special master, the parties, or other interested individuals-proposals regarding the structure and application of the equitable trust. The court will either select a plan or draft one of its own and enter an order describing the plan in detail. ${ }^{62}$ This

59. The positive value ascribed to these activities may be largely subjective; courts will have to make some difficult value choices in creating equitable trusts. $A$ s described infra at note 68 , these judgments should not be made in an arbitrary, paternalistic fashion. Class surveys, expert witnesses, demographic studies, input from named plaintiffs and class counsel, and other methods may assist the court in determining the value of various applications of the recovery fund.

60. This ongoing institution need not exist in perpetuity, nor even over a period of many years. It should, however, be capable of conferring a sustained benefit over time, rather than a mere one-time disbursement of very small amounts.

61. For example, the recovery fund from a class action alleging price fixing might be used to uncover and prosecute similar pricing violations in the marketplace. Courts have an obligation to design remedies that further statutory policy objectives. J.I. Case Co. v. Borak, 377 U.S. 426,433 (1964).

62. Nlthough they involve a settlement, two opinions by Judge Weinstein in the "Agent Orange" case provide an excellent example of how a court can structure an equitable trust. In May 1984, a settlement was reached in a class action suit on behalf of Vietnam veterans and their family members against seven chemical companies for injuries allegedly caused by exposure to certain phenoxy herbicides used in Vietnam. In his opinion approving the $\$ 180$ million settlement, Judge Weinstein offered a number of suggestions for the parties to consider in recommending distribution plans to the court. In $r e$ "Agent Orange" Prod. Liab. Litig., 597 F. Supp. 740, 858-62 (E.D.N.Y. 1984). These suggestions included using the recovery fund to provide: (a) partial direct compensation for veterans suffering adverse health effects; (b) legal and political advocacy on behalf of Vietnam veterans; (c) genetic and family counseling programs; and (d) assistance to class members' children with birth defects. Id. at 858-61. In addition, the court stressed that transaction costs should be minimized, class members should have substantial representation on any governing bodies overseeing the expenditure of funds, and a separate distribution plan should be developed for a subclass of Australian and New Zealand veterans. Id. at 858-59. In a subsequent opinion, the court accepted the proposal of the special master that combined direct compensation and an equitable trust in a single plan. In re "Agent Orange" Prod. Liab. Litig., 611 F. Supp. 1396 (E.D.N.Y. 1985). Three-quarters of the settlement fund was earmarked for direct payments to class members who suffered death or total disability due to "Agent Orange" exposure. Id. at 1410. The court allocated most of the remaining funds to create a class assistance foundation to "serve many purposes" including providing "a national focus for Vietnam 
order will govern the actions of those ultimately selected to administer the trust.

The court may design consumer trusts either to provide services ${ }^{63}$ to class members or to advocate their interests. ${ }^{64}$ Service-oriented trusts stress compensatory principles; those providing advocacy (whether legislative, administrative, or legal) serve principles of deterrence as well, by empowering the plaintiff class. Advocacy trusts promote important public policy goals by functioning as "private attorneys general" to strengthen enforcement of statutes and to discourage predatory market practices, toxic chemical exposures, defective products, or other commercial harms at issue. Advocacy-oriented trusts are analogous to class actions in that a visible few actively assert the rights of all others similarly situated.

The mandated use of the recovery fund should be narrowly drawn to ensure the most accurate "fit" with the interests of the class. As with all fluid recoveries, imperfections will almost certainly appear, the most common being over-inclusiveness-some consumers may benefit from the trust even though they were not injured by defendant's action. To the extent that these "free-riders" benefit because their interests happen to coincide with the interests of the class members served by the fund, this is of only

veterans who are class members to mobilize themselves and others to deal with their medical and related problems. ... In addition, the foundation will provide class members with leverage in seeking to make public and private institutions more responsive to the medical problems of the class." Id. at 1432. The funds allocated to the foundation were to be divided between two uses: aiding children with birth defects; and providing legal and social service projects to meet the needs of the class as a whole. Id. The court specified that the foundation would be "a funding rather than service organization" in that it would provide, on a grant or contract basis, funding to other organizations that would provide services directly to class members. Id. at 1433 . The court would appoint the initial board of directors, which would have between 15 and 45 members and would be comprised primarily of Vietnam veterans. Id. at 1434. The board, with the involvement of an experienced executive director, would define the foundation's funding priorities, submit annual audits and reports to the court for review, solicit and evaluate grant applications and contract offers, and in general "control every aspect of foundation administration." Id. at 1435 . While the board would act on a fully independent basis, the court would retain jurisdiction over the endowment until all funds have been disbursed. In April, 1987, the Court of $\Lambda$ ppeals for the Second Circuit struck down several aspects of the settlement, including the foundation mechanism. See In re "Agent Orange" Prod. Liab. Litig., Nos. 86-3039, -3042, -6171, -6173, -6174 , slip op. $2523,2534-38$ (2d Cir. Apr. 21, 1987). The court found no fault with setting aside a portion of the proceeds from a settlement for programs designed to assist the class as a whole. Id. at 2536. However, it was concerned that in this case the foundation had been granted too much independence; the court believed that increased judicial supervision was necessary. Id. at 2536-37. The court also indicated that it viewed political advocacy to be an inappropriate use of court-administered settlement funds. Id. at 2537-38.

63. For example, consumer trusts could be established to weatherize homes, conduct product testing, offer financial counseling, provide information on prices and quality of competing brands of consumer goods, or educate consumers about their legal and administrative rights and remedies.

64. For example, consumer trusts might be designed to represent consumers in proceedings before state insurance commissioners, professional licensing boards, air and water quality boards, and landfill and hazardous waste siting panels. Consumer trusts might lobby Congress, state legislatures, and city councils to expand health and safety programs, strengthen housing standards, or streamline small claims court procedures. Consumer trusts might also provide legal representation to individual consumers or classes of consumers. 
minor concern; the benefits to class members from advocacy, research, or public education, for example, are not necessarily diminished ${ }^{65}$ because they are delivered in an over-inclusive fashion. ${ }^{68}$

Of more concern is a use of the recovery fund that is either underinclusive (some class members do not share in the benefits) or that allows uneven distribution of benefits (all class members benefit, but some more than others). The more heterogeneous the class, the more difficult it will be to identify interests shared by all, increasing the danger of under-inclusiveness. Class members do have at least one common interest: They all participated in an economic transaction that gave rise to the injury. Under-inclusiveness can therefore be minimized by designing a use for the recovery fund that relates closely to the event leading to the injury and that shares the same substantive goals as the statute under which the suit was brought. Should the problem of uneven benefits persist, the fund might be divided into more than one use, with each specially tailored to the needs of the diverse subclasses. ${ }^{67}$ Nonetheless, it would be unduly optimistic to expect all class members to share in the benefits of the trust in exactly equal amounts--some unevenness is inevitable. But because equitable trusts can be tailored to meet the interests of a particular class, ${ }^{68}$ their use minimizes the over- and under-inclusiveness that can be excessive in the escheat and claimant fund sharing models, respectively.

65. For a discussion of non-rival public goods, see Silver, Utilitarian Participation, 23 Soc. ScI. Info. 701, 711-13 (1984); Snidal, Public Goods, Property Rights, and Political Organizations, 23 INr'ı. Srul. Q. 532, 542 (1979).

66. A primary goal of a consumer trust as a recovery mechanism is, obviously, to provide some compensation to injured class members. If non-class members benefit from the fund as well, this is simply a bonus created by this particular application of the recovery fund. It is quite another matter when the free-riders' benefit from the trust results in a reduced benefit to class members. The court's goal in tailoring the use of the recovery fund is to achieve maximum benefit for class members. Stated otherwise, the court should allow non-class members to benefit from the recovery only if it determines that the recovery fund is being applied to afford class members maximum benefit.

67. This approach should be used sparingly, since it creates additional administrative costs and thereby dilutes the benefits of a single, class-wide disbursement. But see In re "Agent Orange" Prod. Liab. Litig., 611 F. Supp. 1396, 1400 (E.D.N.Y. 1985) (separate treatment for veterans suffering death or disability, and for Australian and New Zealand claimants).

68. Implicit here is the assumption that the interests of class members can be accurately determined. The ultimate decision as to what those interests are, and how they should be served by the recovery fund, belongs to the court. The court will make this decision either in the context of final judgment or, more likely, in reviewing a proposed settlement. See Developments in the Law-Class Actions, 89 Hakv. L. Rkv. 1318, 1373 n.5 (1976). When class members' interests are not evident, the court may seek more data for its decision. This may involve commissioning a study or soliciting advice from experts. Surveys administered to samples of identifiable class members might yield input from individuals who would not otherwise have been sufficiently motivated to come forward. Separate counsel may be appointed to represent subclasses with idiosyncratic views. And the court will undoubtedly permit suggestions by the class counsel and named plaintiffs-those individuals entrusted under Fr.D. R. Crv. P. 23 to represent the interests of the class. These approaches may increase administrative costs, but, relative to very large class-wide damage funds, not significantly. They should nonetheless be used prudently, balancing these costs against the costs of administering alternative damage distribution mechanisms. For a discussion of equitable trust administrative costs, see infra Section IV.B. 
Once the court has determined and published the goals of the equitable trust, it must appoint a responsible, visible individual or board of individuals to direct the operations of the trust and to make detailed funding decisions within the parameters of the court's instructions. One option is to create a new entity to carry out the work of the trust. The recovery fund would become its operating budget, and staff would be hired to complete the work. A second option, preferable to the first in terms of avoiding organizational costs, is to place the money in trust with an existing group experienced in the relevant field. ${ }^{68}$ Non-profit consumer, environmental, neighborhood, and charity organizations are all appropriate recipients. A third option would be to create a foundation that would allocate the funds as grants to deserving organizations for projects that comply with guidelines stipulated by the court. The money could be disbursed over a set period of time, or it could be maintained as an endowment fund with its earnings allocated on an annual basis. ${ }^{\mathbf{7 0}}$ This last approach would have the benefit of creating an entity capable of continuing service, with the flexibility to reorient the use of the fund ${ }^{71}$ as the interests of class members changed over time.

Monitoring costs create no serious impediment to the use of equitable trusts. ${ }^{72}$ Before the court's final order is entered, the directors of the trust would agree to be bound by the limitations placed on the fund by the court and to act as fiduciaries for class members. The court could retain jurisdiction over the trust to facilitate corrective measures should this fiduciary duty be violated. The court might require periodic reports and audits to facilitate oversight, ${ }^{73}$ or even commission an independent evaluation of the workings of the trust. ${ }^{74}$ The very nature of the trust ensures that its

69. State v. Levi Strauss \& Co., 41 Cal. 3d 460, 475, 715 P.2d 564, 573, 224 Cal. Rptr. 605, 614 (1986). The court warned against possible conflicts of interest created when an organization views a recovery as a source of funding for "projects ranked high on [its] own agenda but of little or no benefit to the class." Id. at n.11.

70. Where the court chooses to place the funds in trust with an existing organization, the board of directors of the trust would probably be the directors or staff of the existing group. Where the court chooses to create a new organization or endowment, the board members should be chosen with an eye towards either particular expertise in the field of application or credentials that indicate an ability to represent particular interests of class members. The group might include community leaders, named plaintiffs, or class counsel. As with any fiduciary relationship, it is important to avoid conflicts of interest in appointing this board. See, e.g., In re "Agent Orange" Prod. Liab. Litig., 611 F. Supp. at 1434-35 (board should reflect cross-section of Vietnam veteran community).

71. Any reorientation of the use of the fund would have to be within the parameters of the original court order. Any more extensive change would require approval from the court.

72. In re "Agent Orange" Prod. Liab. Litig., 611 F. Supp. at 1436 ("A comparatively modest supervisory role in the operation of the class assistance foundation will [be satisfactory].").

73. Id. ("The board will submit detailed annual budgets, biannual budgetary status reports, and biannual financial and investment statements to the court for review.").

74. Becrause class members may not have a sufficient economic interest in the trust to provide monitoring, there may be some concern that no one will call the court's attention to misuse of the fund. Reporting and auditing requirements should be designed with this in mind. This concern, how- 
operation would be highly visible and subject to the scrutiny of class members and the public.

\section{B. Expanding the Use of Equitable Trusts}

The equitable trust has achieved a judicial acceptance that is, at best, mixed. Although no court has created a consumer trust as part of a final judgment in a class action, several have approved settlements that include equitable trust provisions. ${ }^{75}$ There are ample cases that offer the opposite

ever, may be unfounded, as the size and public nature of the fund will encourage oversight by the press, governmental authorities, and class members themselves-motivated less by concern over any personal economic stake than by moral indignation at corruption, incompetence, or institutional failure.

75. California has proved the most fertile ground for consumer trusts. Five years ago, a state appellate court overturned a lower court ruling striking the portion of plaintiff' complaint seeking a cy pres recovery (either a price mechanism or an earmarked escheat was requested). The case, Bruno v. Superior Court, 127 Cal. App. 3d 120, 179 Cal. Rptr. 342 (1981), was a private antitrust suit on behalf of between 1 and 1.5 million consumers, charging three supermarkets with fixing milk prices. The appellate court held that, depending on the intent of the substantive law and the circumstances of the case, a cy pres recovery might be appropriate.

Encouraged by this ruling, a California court approved a settlement in a 1984 case creating a prototype consumer trust. Vasquez v. Avco Fin. Servs., No. NCC 11933B (Super. Ct., Los Angcles, Sept. 23, 1975) (settlement approval entered $\Lambda$ pril 24, 1984), involved a class action on behalf of 90,000 consumers alleging excessive interest rates on retail installment sales loans. $\Lambda t$ the suggestion of an intervenor, the California Department of Consumer Affairs, the parties agreed that any portion of the recovery fund that could not be reimbursed to injured consumers would be placed in trust with Consumers Union, a non-profit consumer advocacy organization. These funds were designated for a wide range of activities to benefit class members who did not receive a refund, including administrative, legislative, and legal advocacy; and research, education, and direct service projects. Consumers Union was directed to use part of the fund to review the problems and needs of low- and moderateincome people in California regarding consumer credit transactions, consumer financial issues, and other related matters. Consumers Union received nearly $\$ 325,000$ on behalf of members of the class who could not be identified. Later, another $\$ 1$ million was placed in the trust representing checks sent to consumers that were returned uncashed or undeliverable. The trust fund is administered under the supervision of a fifteen member $\Lambda$ dvisory Council.

State v. Levi Strauss \& Co., 41 Cal. 3d 460, 715 P.2d 564, 224 Cal. Rptr. 605 (1986), is another case in which an intervenor requested the creation of a trust. Levi Strauss \& Co. was charged with fixing prices on mens' and boys' jeans sold in California from 1972 to 1975. The parties settled the case for $\$ 12.25$ million, to be distributed through a lenient claims procedure following a direct mail and media campaign costing $\$ 1.8$ to 2.2 million and reaching every household in the state. Consumers Union, as amicus curiae, joined with other citizen groups as intervenors to ask the court to modify the distribution plan. The intervenors' proposal would have allowed consumers submitting claims to choose whether to receive a fixed amount (thirty cents per pair of jeans) or allocate it to a consumer trust. Any unclaimed funds would also be placed in the trust. Amici Curiae Brief of Consumers Union, et. al., at 46-49, State v. Levi Strauss \& Co., 41 Cal. 3d 460, 715 P.2d 564, 224 Cal. Rptr. 605 (1986) (No. S.F. 24,699) (filed May 23, 1984). The intervenors' motion was rejected by the trial court. On appeal, the California Supreme Court approved the original distribution plan, calling it a "fait accompli" and noting that \$1.5 million of consumers' money had already been spent to administer it. 41 Cal. 3d at 470-71, 715 P.2d at 569-70, 224 Cal. Rptr. at 610-11. The court went on to discuss the merits of using the "residue" of the fund-money remaining after individual distributions-to establish a consumer trust. The idea, the court concluded, "has considerable merit." Id. at 479,715 P.2d at 576, 224 Cal. Rptr. at 617. The case is now on remand to the trial court to determine a plan for the residue of the fund.

Consumer trusts have also gained some acceptance outside California. Part of the $\$ 180$ million settlement of In re "Agent Orange" Prod. Liab. Litig., 611 F. Supp. 1396 (E.D.N.Y. 1985) (approval of distribution plan), was earmarked for a trust fund to provide social services and advocacy for 
view, however, rejecting the use of $c y$ pres and fluid class recoveries, ${ }^{76}$ or specifically, equitable trusts. ${ }^{77}$ In countless other cases the option was never considered, although it may have been appropriate. ${ }^{78}$

Expanding the use of equitable trusts in small claim consumer class actions requires analysis of the objections commonly raised to their application. The first, and possibly least problematic objection, is the claim that aggregating class-wide damages deprives the defendant of due process rights to challenge individual damage claims. ${ }^{79}$ To the extent that the defendant has defenses to assert against certain class members, this claim is probably valid. But with respect to aggregating the claims of similarly situated class members, due process does not require adjudication of each claim individually. Defendant's access to full procedural rights in a single trial to determine the aggregate class-wide damages is sufficient. ${ }^{80}$ Thus, defendant has ample opportunity to challenge any alleged double-recov-

Vietnam veterans who were exposed to " $\Lambda$ gent Orange." The trust was also designed to fund projects to aid children with birth defects born to these veterans. On appeal, the trust was struck down for inadequate judicial supervision. In re "Agent Orange" Prod. Liab. Litig., Nos. 86-3039, -3042, $-6171,-6173,-6174$, slip op. 2523, 2534-38 (2d Cir. Apr. 21, 1987). See supra note 62.

In Bebchick v. Public Util. Comm'n, 318 F.2d 187 (D.C. Cir.), cert. denied, 373 U.S. 913 (1963), the court struck down an improper transit fare increase. Although not a class action, the court ruled that the overcharges should be utilized for the benefit of the entire injured class. The court established a fund administered by the Public Utilities Commission on behalf of transit users.

76. E.g., Windham v. American Brands, 565 F.2d 59, 66 (4th Cir. 1977) (Sherman Act violation); Van Gemert v. Boeing Co., 553 F.2d 812, 815-16 (2d Cir. 1977) (breach of contract with convertible debenture holders); In re Hotel Tel. Charges, 500 F.2d 86, 90-91 (9th Cir. 1974) (conspiracy to inflate hotel charges); Eisen v. Carlisle \& Jacquelin, 479 F.2d 1005, 1018 (2d Cir. 1973) (Securities Exchange $\Lambda \mathrm{ct}$ violation), vacated and remanded on other grounds, 417 U.S. 156 (1974); Reader v. Magma-Superior Copper Co., 110 Ariz. 115, 116, 515 P.2d 860, 861 (1973) (damages sought against owners of copper smelters for polluting air); Lucas v. Pioneer, Inc., 256 N.W.2d 167, 179 (Iowa 1977) (damages sought against producers of defective seed corn).

77. E.g., In re Folding Carton Antitrust Litig., 744 F.2d 1252 (7th Cir. 1984) (price fixing); Simer v. Rios, 661 F.2d 655 (7th Cir. 1981), cert. denied, 456 U.S. 917 (1982) (denial of emergency energy relief funds); Cicelski v. Sears, Roebuck \& Co., 132 Mich. App. 298, 348 N.W.2d 685 (1984) (miscalculation of department store finance charges).

78. E.g., In re Cuisinart Food Processor Antitrust Litig., 1983-2 Trade Cas. (CCH) I 65,680 (D. Conn. 1983) (price fixing); Colson v. Hilton Hotels Corp., 59 F.R.D. 324 (N.D. Ill. 1972) (illegal telephone charges on hotel room bills); Blue Chip Stamps v. Superior Court, 18 Cal. 3d 381, 556 P.2d 755, 134 Cal. Rptr. 393 (1976) (excess sales tax charges).

79. Eisen v. Carlisle \& Jacquelin, 479 F.2d 1005 (2d Cir. 1973), vacated and remanded on other grounds, 417 U.S. 156 (1974). "Even if amended Rule 23 could be read so as to permit any such fantastic procedure [as fluid recovery], the courts would have to reject it as an unconstitutional violation of the requirement of due process of law." Id. at 1018.

80. See Developments in the Law-Class Actions, supra note 68, at 1524-25; Comment, Due Process and Fluid Class Recovery, 53 Or. L. Rrv. 225, 236-37 (1974); Recent Developments, Eisen III: Fluid Recovery, Constructive Notice and Payment of Notice Costs by Defendant in Class Action Rejected, 73 Col.um. L. Rrv. 1641, 1648-49 (1973). Subsequent courts' rejection of the Eisen due process concern is implicit in their use of class-wide damage aggregation. See, e.g., Van Gemert v. Boeing Co., 590 F.2d 433 (2d Cir. 1978) (securities case in which damages were aggregated through use of formula multiplying difference in stock price by number of shares at issue), aff d, 444 U.S. 472 (1980); Roper v. Consurve, Inc., 578 F.2d 1106 (5th Cir. 1978) (bank's computer records used to calculate class-wide damages), aff'd on other grounds sub nom. Deposit Guar. Nat'l Bank v. Roper, 445 U.S. 326 (1980). 
eries on the part of individual class members that would inflate the aggregate class-wide damages. Further, limiting defendants to a single hearing on aggregate damages can be no more violative of due process than collateral estoppel, which would ultimately have the same effect if hearings for determination of each class member's damages were required. ${ }^{\mathbf{8 1}}$

A second objection is the claim that this type of cy pres distribution violates Rule $23^{82}$ and the Rules Enabling $\mathrm{Act}^{83}$ by violating the ban on altering substantive rights. ${ }^{84}$ Alone, this claim is not dispositive. Courts must first analyze the specific substantive rights of the parties under the statute invoked to determine whether they have been altered by this application of Rule 23. When plaintiffs sue under statutes drawn to serve principles of deterrence and disgorgement, it is difficult to argue that application of an equitable trust, which accomplishes these goals, conflicts with the Rules Enabling Act by altering the parties' substantive rights. However, if plaintiffs invoke statutes drawn explicitly to provide compensation to a narrow range of injured parties, a conflict may result. Since the goals of deterrence, disgorgement and compensation are usually inherent-albeit in varying proportions-in most statutes relevant to the consumer class actions discussed here, the analysis becomes complex. The court must determine the strength and clarity of the legislative concern for each of these goals to evaluate the appropriateness of $c y$ pres distributions.

Legislatures can facilitate this judicial inquiry by recognizing that explicit attention to only the compensatory function of a statute may, in the class action remedy context, eclipse any real but unstated concern with deterrence and disgorgement. The result, as we have seen, may be an insurmountable barrier to the use of Rule 23 to correct the statutorily recognized wrong, at least when the individual claims are relatively small. In the end, even the goal of compensation is not achieved. To ensure that the statute will provide full protection, the legislature must explicitly recognize, in both the legislative history and the statutory language itself, the goals of deterrence and disgorgement. While this is easy enough for future legislative action, it is cumbersome, and perhaps fraught with political barriers, to amend existing consumer protection statutes already enacted. Yet this may be the only way to allow cy pres remedies to be applied, thereby guaranteeing fair application of these statutory protections to all meritorious claims.

81. See Developments in the Law-Class Actions, supra note 68, at 1525.

82. Fr.D. R. Civ. P. 23.

83. 28 U.S.C. $\$ 2072$ (1982).

84. See In re Hotel Tel. Charges, 500 F.2d 86, 90 (9th Gir. 1974); Eisen, 479 F.2d at 1014; see also Simon, supra note 2. But see $2 \mathrm{H}$. Nrwber(;, supra note $5, \S 10.22$, at 386 (" $C y$ pres is a substantive law principle. It is not a procedural rule that would be barred from enlarging, modifying, or abridging substantive rights, contrary to the Rules Enabling Act."). 
The courts can respond to this objection as well, by designing cy pres remedies with particular care. The crux of the criticism is that these remedies are insufficiently compensatory in nature to satisfy statutes that are explicitly compensation-oriented. In "gray area" cases in which the statute expresses a mix of compensatory and deterrent/disgorgement goals, the court should be particularly careful in framing the use of the trust fund. To the extent that the use of the fund is tailored to benefit class members only, and each to a degree commensurate with his or her injury, its compensatory nature is emphasized. Only when there is significant variance between this alternative application of the recovery fund and individual disbursements is the critic's claim strengthened. Special efforts by the courts to determine the best application of the fund-surveys, experts, subclassing, and other methods-will be crucial in meeting this concern.

A third objection to the use of equitable trusts is the claim that the judiciary enjoys too much discretion already, and that equitable trust remedies would further expand this discretion. ${ }^{85}$ In the class action context, judicial restraint favors the traditional compensation-oriented approach, which, we have seen, often serves to extinguish the recovery prospects of class members with small individual claims. The legislature can overcome this objection by enacting a statute that brands cy pres remedies not merely an acceptable exercise of judicial discretion, ${ }^{86}$ but a preferred exercise when the alternative is a failure to satisfy otherwise valid claims of class members. This requires a bright-line rule, to be engrafted upon Rule 23 , its state law equivalents, or substantive statutes that give rise to classwide causes of action. The rule would set standards to trigger the use of $c y$ pres when the meritorious claims of class members-with special concern for absentee class members-might otherwise be imperiled.

\section{Proposed Statutory Guidelines}

In theory at least, there are no insurmountable barriers to expanded use of equitable trusts. Generally, courts have sufficient discretion under their equity powers to invoke this alternative remedy. Despite the latitude to create equitable trusts, in practice courts rarely do. Express legislative guidance would help overcome this judicial inertia. ${ }^{87}$ This Note proposes three major guidelines.

85. Chayes, The Supreme Court, 1981 Term-Forward: Public Law Litigation and the Burger Court, 96 Harv. L. Rrv. 4, 46 (1982).

86. Indeed, the court is no less qualified to determine the best application of the recovery fund than it is to approve a class action settlement that deviates from the relief originally requested.

87. Two legislative proposals concerning class action recovery procedures merit attention. Neither adequately meets the concerns raised in this Note. The UNIFORM CLASS ACTIONS ACT, reprinted in 12 U.L.A. 23 (Supp. 1986), adopted in lowa and North Dakota, fails in two important respects. First, the Uniform Class $\Lambda$ ctions $A$ ct (UCA $A$ ) explicitly invites the court to balance the size of indi- 
A. Direct compensation of individual class members shall be the favored remedy in class action suits providing it is fair and feasible. If not, class-wide damages shall be aggregated and a single recovery fund created.

This guideline preserves the compensation-oriented status quo. I suggest a three-part test to determine when direct compensation, via individual proofs of claim, is no longer fair or feasible. The first part determines that a more equitable option does not exist for claimants outside the class action approach. The second part determines that a class-wide recovery is possible. And the third part determines that, once the class action route has been taken, a class-wide distribution is necessary in order to achieve an equitable recovery for all deserving class members.

1. It is unlikely that class members will prosecute their claims individually if denied use of the class action mechanism. If the amount or nature of plaintiffs' claims are such that the court could reasonably believe that all but an insubstantial number of class members would seek direct compensation through individual actions, then there is no justification for requiring alternative recovery mechanisms. In these cases, noncertification of the class would be preferable because few individual claims will go unprosecuted. Our concern is with suits involving monetary claims that are so small that only the economies of scale provided by the class action device justify their pursuit.

2. It is possible to calculate the aggregate class-wide damages. In most cases, access to the defendant's own records is sufficient, and, indeed, the most accurate method of calculating aggregate class-wide damages. For instance, in a price-fixing suit charging the defendant with illegally inflating the price of its product, the defendant's sales figures are likely the only

vidual claims against administrative costs and to consider other management difficulties in deciding whether to allow the class action to proceed. $I d$. $\S 3(11),(13)$. This is a clear invitation to deny certification to small claim actions involving large plaintiff classes. Second, the Act requires that all funds remaining after distribution to identifiable class members escheat to the state. Id. $\S 15(c)(5)$. Thus, absentees would receive no benefit (except a de minimis reduction in taxes), either directly or through cy pres.

The Federal Consumer Class Action $\Lambda$ ct, see The Federal Consumer Class Action Act, 4 Cl.Ass Acrion RFp. 342 (1975), proposed in 1976 but never enacted by Congress, avoids at least one of the UCA A's shortcomings by refusing to allow courts not to certify an action for damages due to manageability difficulties, including problems in distributing any recovery. The statute specifically provides for class-wide aggregation of damages and a class-wide distribution through cy pres, when appropriate. Id. at 344-45. The problem with this proposed statute is that it is designed only to provide a new federal cause of action to combat consumer fraud. Thus, its progressive approach to $c y$ pres distributions is limited to this particular cause of action. Further, it does not adequately protect the interests of absentees. Before any cy pres distribution is made, the $\Delta$ ct requires efforts to identify and compensate individual class members. These efforts are limited to those justified by the probable benefits to be achieved in compensating individual consumers. Id. at 345. The expense of individual compensation may be justified from the perspective of those receiving the money, but not from the perspective of the absentee claimants who must underwrite the effort. The result is a subsidy by the absentees to the identifiable class members. 
reliable indicator of the total damages. In other cases, it may be necessary to use statistical sampling or other econometric techniques to arrive at a reasonably accurate calculation of damages. The courts would be justified in refusing aggregate recovery only when records are unavailable, and reliable estimates are impossible.

3. Either (i) it is reasonably certain that a substantial portion of the plaintiff class will not present proofs of claim, or (ii) the cost of identifying and compensating individual class members is excessive relative to the cost of a class-wide distribution. The former criterion could apply when there is a large pool of unidentified or unidentifiable class members. Perhaps the small size of the claim provides insufficient economic incentive for individual claimants to come forward; or the nature of the claim may be such that it is difficult for claimants to provide individual proofs of claim. ${ }^{88}$ In either case, the controlling principle is that a significant portion of the class may fail to recover on otherwise valid claims.

The latter criterion focuses on the total cost of identifying individual class members, communicating with them, adjudicating their claims, and distributing their recoveries. This concern involves the court's judgment as to whether administrative costs are too high to insist upon a direct compensation scheme. The feasibility of either approach is ultimately determined by comparing the administrative costs with the size of the recovery itself. The court must do more than simply ascertain whether administrative costs are greater for direct compensation than for cy pres; this alone may not justify applying cy pres. The court must determine if administrative costs are excessive. The costs of the cy pres distribution act as the much-needed reference point.

B. The class-wide recovery fund shall be used to compensate individual claimants as appropriate, but only to the extent that doing so does not sacrifice the interests of absentee class members; the remainder of the fund shall be distributed through cy pres.

Claimants should receive direct compensation when it can be accomplished efficiently. Some claimants may deserve individual treatment either because their claims are larger than most, justifying greater expense to administer their distribution, or because these individuals are already identified, making direct compensation relatively inexpensive. The efficiency rationale which justifies cy pres class-wide distributions does not apply to these claimants; direct compensation is appropriate.

A problem arises, however, if the recovery of identifiable class members occurs at the expense of absentee members. Because administrative costs are generally incurred on a class-wide basis, they are chargeable to the

88. See supra Section I.A. 
entire recovery fund; all class members bear a pro rata share. If identifying and compensating identifiable class members uses up a disproportionate share of the recovery fund, then the recoveries of absentee class members are diminished, and the absentee class members are, in effect, subsidizing the identifiable members.

How should the court determine whether direct compensation to identifiable class members creates this subsidy? Obviously, what is important is not the total costs spent on each recovery mechanism, but rather a relative measure of these costs. This is best calculated on a cost per class-memberrecovery basis, or, stated differently, the average administrative expense each method incurs for each class member who recovers by that method. ${ }^{\mathbf{8 9}}$ If the cost per class-member-recovery for direct compensation exceeds that for cy pres, then a subsidy is taking place. Because the administrative expense of a cy pres recovery is so low, direct compensation will occur rarely under this test-and only under conditions that render it extraordinarily efficient (e.g., the claimant has already stepped forward with a claim easily recognized as valid). The equitable principle of protecting the recoveries of absentees, rather than any bias against direct recoveries, justifies this approach. ${ }^{90}$

89. Cost per class-member-recovery is preferable to cost per dollar awarded (i.e., total administrative costs divided by total award dollars disbursed) for three reasons. First, to the extent that the size of the claim per class member is uniform, there will be no difference between the calculations. Second, even where the size of the claims are not uniform, a cost per class-member-recovery calculation may be fairer and more accurate. The administrative costs most frequently at issue here are (a) identifying and communicating with the member, (b) ascertaining the legitimacy and amount of the claim, and (c) disbursing compensation. The size of the claim has little or no effect on disbursement costs-it is no more costly to write a check and do the bookkeeping for a five dollar reimbursement than for a fifty dollar reimbursement. Since we are interested only in small individual claim litigation, the administrative costs of ascertaining the legitimacy and amount of the claim will likewise vary only minimally, if at all, with the size of the claim. The claimant bears any costs of gathering and presenting necessary proofs of claim, so there is no danger that absentee members will subsidize these costs. The real classwide cost here is the expense of setting up a system to adjudicate the legitimacy of the individual claims. Once the system is set up, the incremental cost of adjudicating fifty dollars of claims over five dollars of claims is nominal. The cost of identifying and communicating with class members will likewise be no different for a fifty dollar claimant than for a five dollar claimant. In short, these administrative costs vary directly with the number of class members participating, not with the size of their claims.

The third reason why a cost per class-member-recovery method is preferable is self-evident upon application. The object is to determine when it is appropriate to spend a portion of the recovery fund to compensate individual members directly. Many of these members will be unidentified at the time this determination is made. $\Lambda$ cost per dollar of recovery calculation would be useless, since one could not know the amounts of the individual claims without first having identified the members and ascertained the amount of their claims.

90. Society sufficiently values direct compensation that it is willing to incur a disparate cost to accomplish it, See In re "Agent Orange" Prod. Liab. Litig., 611 F. Supp 1396, 1410 (E.D.N.Y. 1985) ("The common law generally holds that money damages are a preferred remedy."). This is reflected in the approach of this Note's Guideline 1.3.: It is not enough that the costs of administering a direct compensation scheme are greater than for cy pres; they must be excessive before cy pres will be invoked. Nonetheless, it is inappropriate to incur a disproportionate cost to accomplish direct compensation for only some members of the class when the cost is being borne by other class members. Small claim mass consumer class actions by nature have a very large percentage of absentee class 
It is important to note that under an equitable trust distribution, all class members can benefit to the same degree. Even though some class members may avail themselves of the services provided by the trust more than others, the opportunity to benefit is provided to the class on an equal basis. As a result, inequities may occur if the claims of class members are not uniform. For example, if the injury of one claimant is $\$ 100$ when the average claim is only $\$ 10$, a cy pres distribution may undercompensate that person. ${ }^{91}$

There are two ways to address this problem. One approach is to group larger claims in a subclass for separate treatment-either an entirely separate action or a separate recovery fund. It would of course be relatively expensive to identify these larger claimants among a very largé consumer class and to administer their recoveries. To the extent that their individual claims are large enough to justify this expense, this is a viable solution. Where they are not, grouping them with the smaller, average claimants may be the lesser of two evils, and the only way of ensuring any recovery.

The second approach is to allow these claimants to recover individually, but to require them to bear the additional administrative costs. To do otherwise would force the smaller claimants to subsidize their recoveries. Only those efforts likely to yield a benefit greater than the sum of these administrative costs and the value of the cy pres recovery would be justified. Stated differently, the court should seek to compensate these claimants directly only to the extent that the benefits of direct compensation minus the unsubsidized costs exceed the benefits of $c y$ pres. The smaller the individual claim, the less justified direct compensation would be; and as the claims become larger, individual recoveries would be encouraged.

members. See supra Section I.C. Any recovery mechanism in these cases should be structured to recognize the absentees' equal right to compensation.

Some may argue that the individuals who actively prosecuted the suit deserve to be compensated directly to recoup their time and energy costs. This is unrealistic. These are actions to recover on small individual claims-in most cases so small that full direct compensation will not meaningfully reward them for their actions. It is safe to assume that these active plaintiffs are motivated by the more principled goals of deterrence, disgorgement, and class-wide benefit rather than by personal financial gain.

91. The benefits conferred by a cy pres equitable trust may be disproportionate to the size of individual contributions to the fund. See supra Section III.A. There are obvious difficulties in valuing the return on a cy pres distribution, since it is delivered not in financial form, but in services, advocacy, education, increased health and safety, enhanced opportunities, and so on. Nonetheless, the pitfall described here is real: $\Lambda$ claimant with a substantially larger than average claim may have a greater interest in a direct distribution of the recovery fund than one with a smaller claim.

This is offset to some degree by a related, mirror-image problem. Any claimant who recovers individually may also benefit from the cy pres application of the balance of the fund. This potential double recovery contributes to the imperfect fit between any cy pres distribution and a fully accurate direct compensation scheme. However, the nature of the benefit produced by an equitable trust does not diminish in value to class members because non-deserving individuals also benefit from it. See supra note 66 and accompanying text. In this sense, the double recovery issue is more cosmetic than substantive. 
The court would be required to draw on its experience and common sense in determining where to draw the direct compensation line. ${ }^{92}$

C. In devising an appropriate cy pres remedy for the remainder of the recovery fund, the court shall create an equitable trust to benefit the injured class. ${ }^{\text {ss }}$

Of the various $c y$ pres options, the equitable trust is best suited to small claim consumer class actions. ${ }^{94}$ This method of distributing the recovery fund forces the defendant to disgorge ill-gotten gains, deters future illegal conduct, and compensates injured class members (although with services instead of direct payments). This is accomplished fairly and efficiently: all class members-including absentees-benefit equally, and administrative costs are minimized.

\section{ConCluston}

Market strategies, once local or regional in nature, now span vast areas and reach many millions of consumers. As a result, marketplace abuses today injure millions of consumers at once. Yet our legal system remains inept at remedying abuses that exact a small toll from a very large number of people. The judiciary, while capable of responding to this problem, has generally failed to do so. Legislatures must therefore respond by allowing aggregation of damages, promoting the goals of deterrence and disgorgement in large consumer class actions, ${ }^{95}$ and encouraging the use of equitable trust cy pres remedies.

92. This cost-benefit rule of thumb approach is intuitive both in design and application. It is easy to calculate the benefits of direct compensation because they are defined in dollar terms. But the benefits of cy pres, as well as the incremental costs of providing direct recovery to these claimants, are not easily translated into simple dollar terms.

93. Often, courts will need to decide what to do with the residue of funds remaining after attempting to compensate individual class members directly. Particularly when an action has been pending for a number of years, the amount of funds returned due to lack of current addresses for class members can be substantial. For greatest efficiency and class-wide benefit, these funds should be included in an equitable trust. It is important, however, that this is expressly stated in the court's original order. Otherwise, "undeliverable" funds might be considered abandoned property; most states have statutes requiring that unclaimed property escheats to the state. See, e.g., CAL. Civ. Proc. CodE $\$ \$ 1510-1528$ (West 1982). By indicating an alternative use for these funds to benefit the class, courts can avoid the possibility of escheat. Alternatively, escheat statutes can be amended to provide that "unclaimed property" originally allocated as part of a class action distribution shall not escheat to the state but shall instead be applied by the court to benefit the class through cy pres.

94. For a discussion of circumstances in which a price mechanism distribution might be appropriate, see supra notes 44-48 and accompanying text.

95. The focus of this Note is on the application of equitable trusts to a particular species of class action-those with very large consumer plaintiff classes and involving relatively small individual claims. This Note does not argue that the only application of equitable trusts is in this type of action. Indeed, this alternative remedy may be equally well-suited to a variety of class actions in which direct compensation may be problematic. For example, class suits against polluters may present problems of calculation of individual damages best resolved through application of an equitable trust. This may also be the solution to damage award difficulties presented by toxic chemical exposure cases, in which the victims are virtually unidentifiable due to the delayed nature of the injury. Even consumer class actions involving relatively large individual claims may present opportunities for creating equitable trusts which public policy considerations might deem preferable to a direct compensation scheme. 